\title{
Pengaruh Kualitas Rumah dan Lingkungan terhadap Kepuasan Penghuni dan Kecenderungan Berpindah di Perumnas Bukit Sendangmulyo Semarang
}

\author{
Yudhi Widiastomo ${ }^{1}$ \\ Diterima : 19 Agustus 2014 \\ Disetujui : 2 September 2014
}

\begin{abstract}
This study aims to examine the influence of the quality of the house and environment on resident's satisfaction and propensity to move at Bukit Sendangmulyo Housing. This research uses a quantitative approach through questionnaires and field observations. The analysis use descriptive statistical analysis and the analysis of SEM (Structural Equation Modeling). The result of the study show that the environmental quality has a significantly greater effect on resident's satisfaction in Bukit Sendangmulyo Housing with estimated value 0.740 , and for the quality of the house has a small effect on resident's satisfaction with the estimated value 0.231 . Resident's satisfaction has a negative effect on the propensity to move with the estimated value -0.420 . Therefore, the environment quality becomes the most important factor in the quality of living than the quality of the house and need to be noticed in the future development of social housing. The existence of the environment with good and complete infrastructure will make communities comfortable to stay so their propensity to move will be smaller.
\end{abstract}

Keywords : housing satisfaction, propensity to move, structural equation modeling

\begin{abstract}
ABSTRAK
Penelitian ini bertujuan untuk mengkaji pengaruh kualitas rumah dan lingkungan terhadap kepuasan penghuni dan kecenderungan berpindah. Pendekatan yang digunakan dalam penelitian ini adalah pendekatan kuantitatif melalui kuesioner dan observasi lapangan. Analisis yang digunakan adalah analisis statistik deskriptif dan analisis SEM (Structural Equation Modeling). Hasil penelitian menunjukkan bahwa kualitas lingkungan secara signifikan memiliki pengaruh besar terhadap kepuasan penghuni di Perumnas Bukit Sendangmulyo dengan nilai estimate sebesar 0.740 , sedangkan kualitas rumah memiliki pengaruh kecil terhadap kepuasan penghuni dengan nilai estimate sebesar 0.231 . Kepuasan penghuni memiliki pengaruh negatif terhadap kecenderungan berpindah dengan nilai estimate sebesar -0.420 . Oleh karena itu faktor kualitas lingkungan menjadi faktor yang paling penting dalam bertempat tinggal dibanding kualitas rumah dan perlu di perhatikan dalam pengembangan perumahan sosial kedepannya. Adanya lingkungan dengan sarana dan prasarana yang baik dan lengkap akan membuat masyarakat menjadi betah untuk tinggal sehingga kecenderungan mereka untuk berpindah akan semakin kecil.
\end{abstract}

Kata kunci : kepuasan perumahan, kecenderungan berpindah, model persamaan struktural

\footnotetext{
${ }^{1}$ Mahasiswa Magister Pembangunan Wilayah dan Kota, Undip, Semarang, Jawa Tengah Kontak Penulis : iyudhh@gmail.com
} 


\section{PENDAHULUAN}

Perum Perumnas sejak dibentuk melalui Peraturan Pemerintah No. 29 Tahun 1974 sudah banyak menyediakan perumahan bagi masyarakat menengah ke bawah dengan harga jual yang cukup rendah dengan syarat pembayaran yang relatif tidak memberatkan masyarakatnya. Di Kota Semarang sendiri Perum Perumnas sudah banyak membangun perumahan yang terletak di berbagai lokasi seperti Sampangan, Krapyak, Banyumanik, Tlogosari, Sendangmulyo, Jangli, Palir, dan Beringin. Dari kedelapan proyek pembangunan perumnas tersebut terdapat beberapa perumnas yang berkembang pesat dan bisa menjadi pusat pertumbuhan baru seperti pada Perumnas Banyumanik dan Tlogosari serta juga terdapat yang kurang berhasil karena pertumbuhannya yang relatif stagnan seperti pada Perumnas Bukit Sendangmulyo. Berdasarkan penelitian yang dilakukan Widiastomo (2013) ditemukan bahwa rumah yang disediakan melalui Perum Perumnas di Perumnas Bukit Sendangmulyo tidak sepenuhnya dihuni oleh masyarakat. Pada studi penelitiannya yang dilakukan di Perumnas Bukit Sendangmulyo diketahui terdapat kurang lebih 5,5\% rumah yang dibiarkan rusak dan tidak dihuni serta terdapat kapling tanah matang yang dibiarkan terlantar di lingkungan perumnas yang mencapai kurang lebih 14,5\%. Selain itu kondisi Perumnas Sendangmulyo tidak terlepas dari permasalahan penurunan kualitas lingkungan.

Fenomena banyaknya rumah yang tidak berpenghuni dan juga kapling yang tidak termanfaatkan di Perumnas Bukit Sendangmulyo merupakan fenomena yang mungkin terjadi akibat rendahnya kepuasan penghuni berdasarkan kondisi rumah dan lingkungan mereka. Sungguh sangat memprihatinkan bila rumah yang disediakan oleh Perum Perumnas dengan prasarana lengkap, dan disubsidi sehingga harganya terjangkau tersebut justru banyak ditinggalkan. Dari penelitian yang sudah dilakukan oleh Widiastomo (2013) diketahui bahwa kepuasan penghuni berdasarkan kualitas lingkungan di Perumnas Bukit Sendangmulyo termasuk dalam kategori cukup rendah. Menurut Weidemann dan Anderson (1985, dalam Mohit dan Azim, 2012) dijelaskan bahwa studi tentang kepuasaan perumahan pada dasarnya memiliki dua jenis, yaitu sebagai alat untuk memprediksi perilaku (niat untuk tetap tinggal atau pindah dari perumahan yang ada) dan sebagai kriteria untuk menilai kualitas perumahan.

Dengan adanya berbagai permasalahan yang sudah dijelaskan tersebut, penelitian ini dilakukan menggunakan pendekatan kuantitatif dengan mengkaitkan dengan berbagai teori yang sudah ada. Kepuasan perumahan merupakan sebuah konsep yang digunakan untuk mengevaluasi persepsi dan perasaan warga tentang rumah dan lingkungan mereka (Ogu, 2002 dalam Lara dan Bekker, 2012). Oleh karena itu penelitian ini akan berfokus untuk mengkaji pengaruh kualitas rumah dan lingkungan terhadap kepuasan dan kecenderungan untuk berpindah penghuninya. Hasil penelitian diharapkan mampu menghasilkan model pengaruh antara kualitas rumah dan kualitas lingkungan terhadap kepuasan penghuni dan kecenderungan untuk berpindah di Perumnas Bukit Sendangmulyo untuk menjawab berbagai permasalahan yang ada di Perumnas Bukit Sendangmulyo.

\section{METODE PENELITIAN}

Penelitian mengenai hubungan kepuasan penghuni dengan kecenderungan berpindah di Perumnas Bukit Sendangmulyo ini menggunakan pendekatan kuantitatif. Sugiyono (2012: 80) menjelaskan bahwa metode penelitian kuantitatif dapat diartikan sebagai metode penelitian yang berlandaskan pada filsafat positivisme, digunakan untuk meneliti pada populasi dan 
sampel tertentu, pengumpulan data menggunakan instrumen penelitian, analisis data bersifat kuantitatif/statistik, dengan tujuan untuk menguji hipotesis yang telah ditetapkan.

\section{Teknik Pengumpulan Data dan Teknik Sampling}

Pengumpulan data merupakan prosedur yang sistematis dalam suatu penelitian. Teknik pengumpulan data dalam penelitian ini terbagi menjadi dua cara, yaitu pengumpulan data sekunder dan pengumpulan data primer. Pengumpulan data sekunder dilakukan dengan studi literatur dan survei instansi, sedangkan pengumpulan data primer dilakukan dengan observasi lapangan dan kuesioner. Teknik sampling yang digunakan untuk kuesioner dalam penelitian ini mengggunakan teknik probability sampling yaitu proportionate stratified random sampling. Proportionate stratified random sampling merupakan teknik yang digunakan untuk menentukan sampel, bila populasi mempunyai anggota/unsur yang tidak homogen dan berstrata secara proporsional (Sugiyono, 2012). Metode sampling ini dipilih karena Perumnas Bukit Sendangmulyo yang memiliki karakteristik yang berstrata yang ditunjukkan melalui tipe rumahnya, yaitu tipe 21, 36, dan 45. Berdasarkan perhitungan didapatkan hasil jumlah kuesioner yang akan disebarkan kepada penghuni Perumnas Bukit Sendangmulyo adalah 100 sampel yang terbagi 20 sampel rumah tipe 21, 74 sampel rumah tipe 36, dan 6 sampel rumah tipe 45 .

\section{Teknik Analisis}

Teknik analisis yang digunakan dalam penelitian ini adalah structural equation modeling (SEM dan statistik deskriptif. Statistik deskriptif merupakan statistik yang digunakan untuk menganalisis data dengan cara mendeskripsikan atau menggambarkan data yang telah terkumpul sebagaimana adanya (Sugiyono, 2012). Maruyama (1998 dalam Mustafa dan Tony, 2012) menyebutkan SEM adalah sebuah model statistik yang memberikan perkiraan perhitungan dari kekuatan hubungan hipotesis di antara variabel dalam sebuah model teoritis, baik secara langsung atau melalui variabel antara (intervening variables). Senada dengan pendapat tersebut, Pedhazur (1982 dalam Mustafa dan Tony, 2012) menyatakan bahwa SEM mengacu pada hubungan antara variabel endogen (endogenous variables) dan variabel eksogen (exogenous variables), yang tidak dapat diamati secara langsung (unobserved variables) atau variabel laten (latent variables). Variabel endogen dalam penelitian ini adalah kualitas rumah dan kualitas lingkungan, sedangkan untuk variabel eksogen adalah kepuasan penghuni dan kecenderungan berpindah yang mana keempat variabel tersebut adalah variabel laten.

TABEL 1

VARIABEL DAN DATA PENELITIAN

\begin{tabular}{|lcl|}
\hline Variabel & Notasi & Indikator \\
Karakteristik Rumah Tangga & - & Pendapatan \\
& - & Pendidikan \\
Kualitas Rumah & - & Lama tinggal \\
& - & Jumlah anggota keluarga \\
& - & Usia keluarga \\
& X1 & Dinding rumah \\
X2 & Lantai rumah \\
X3 & Atap rumah \\
Kualitas Lingkungan & X5 & Jumlah ruang \\
& X6 & Lokas/tipe rumah \\
& X7 & Kelengkapan prasarana \\
X8 & Kelengkapan sarana \\
\hline
\end{tabular}




\begin{tabular}{|lll|}
\hline & X9 & Tingkat keamanan \\
Kepuasan Penghuni & X10 & Hubungan sosial bertetangga \\
& X11 & Kepuasan terhadap rumah \\
Kecenderungan Berpindah & X12 & Kepuasan terhadap lingkungan \\
& X13 & Niat untuk pindah \\
& X14 & Rencana untuk pindah \\
\hline
\end{tabular}

Sumber: Hasil Analisis, 2014

\section{GAMBARAN UMUM}

\section{Lokasi Perumnas}

Perumnas Bukit Sendangmulyo secara administratif terletak di Kelurahan Sendangmulyo, Kecamatan Tembalang, Kota Semarang bagian selatan. Perumnas ini berjarak sekitar 4,5 km dari kantor Kecamatan Tembalang dan berjarak $11 \mathrm{~km}$ dari pusat Kota Semarang yaitu kawasan Simpanglima. Perumnas Bukit Sendangmulyo memiliki luas kurang lebih 537,493 $\mathrm{m}^{2}$ atau sekitar 53,75 Ha atau sekitar 13 \% dari luas Kelurahan Sendangmulyo. Untuk skala lingkunganya, perumnas ini terbagi dalam 6 RW dan 53 RT. Adapun untuk lebih jelasnya peta wilayah studi Perumnas Bukit di Sendangmulyo dapat dilihat pada gambar berikut ini.

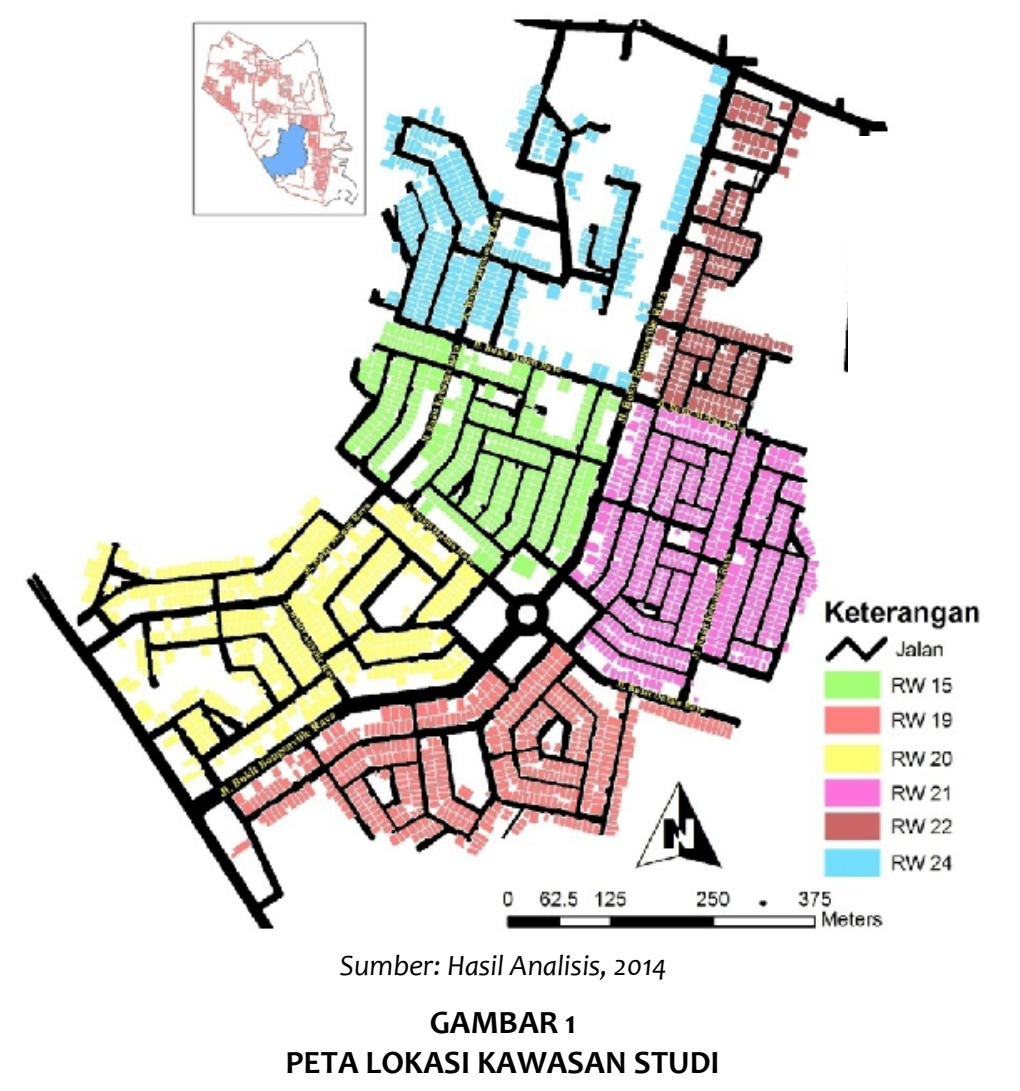

\section{Sejarah Pembangunan Perumnas}

Di Kota Semarang, pengadaan perumahan bagi masyarakata menengah ke bawah dilakukan oleh Perum Perumnas Regional V sejak tahun 1974. Lokasi pembangunan pertama yaitu Perumnas Sampangan, kemudian dilanjutkan oleh Perumnas Krapyak, Banyumanik, Tlogosari, Sendangmulyo, Jangli, Palir, dan terakhir adalah Perumnas Beringin. Perumnas Bukit 
Sendangmulyo dibangun sejak tahun 1994 dengan tipe yang direncanakan adalah tipe 21-RSS, 21-RS,36-RSS, 36 RS, 45, dan KTM (kapling tanah matang). Perumnas tersebut merupakan salah satu pembangunan perumnas dalam Regional $V$ di Kota Semarang yang dibangun oleh pemerintah pusat dengan jumlah unit 2102 dimana dilatarbelakangi karena tingginya kebutuhan rumah di kota tersebut pembangunan perumahan yang terjadi hingga ke daerah pinggiran. Perumnas Bukit Sendangmulyo yang terletak di Kecamatan Tembalang ini mulai dihuni oleh warga sejak tahun 1997.

\section{Karakteristik Rumah}

Perumnas Bukit Sendangmulyo yang dibangun di Kecamatan Tembalang sejak tahun 1994 merupakan perumahan sosial yang dibangun secara terencana dan sudah dilengkapi dengan prasarana yang lengkap. Tipe rumah yang ada di perumnas ini adalah tipe 21-RSS, 21-RS, 36-RSS, 36-RS, dan tipe 45. Masing-masing rumah berada pada lingkungan dengan ukuran jalan yang beragam mulai dari 2-3 $\mathrm{m}$ hingga 7-8 meter. Bangunan rumah pada perumnas ini seluruhnya sudah permanen baik sudah direnovasi maupun masih bangunan asli dari Perum Perumnas. Berdasarkan hasil pengolahan data kuesioner diketahui bahwa kondisi rumah di Perumnas Bukit Sendangmulyo $73 \%$ sudah direnovasi dan sisanya $27 \%$ masih asli bangunan dari Perumnas. Sebanyak 15\% rumah tangga statusnya mengontrak rumah dari pemilik dengan harga yang beragam tergantung kondisi rumah tersebut. Selain itu dari pengolahan data kuesioner diketahui juga bahwa 52\% rumah tangga di Perumnas Bukit Sendangmulyo justru membeli rumah dari pemilik sebelumnnya, bukan dari Perum Perumnas.

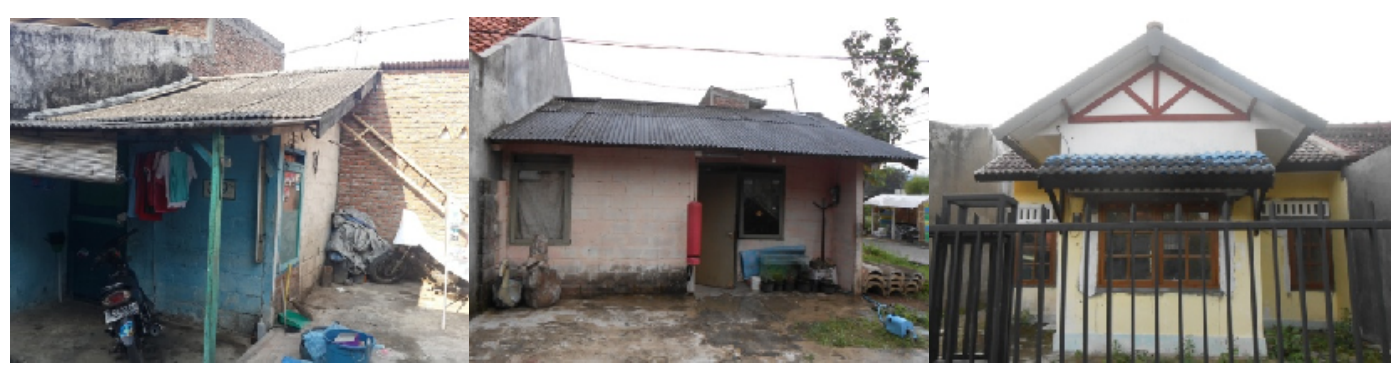

Sumber: Hasil Observasi, 2014

GAMBAR 2

PERBANDINGAN RUANG RUMAH TIPE 21, 36, DAN 45 YANG MASIH ASLI

\section{KAJIAN TEORI}

\section{Kepuasan Penghuni}

Studi tentang kepuasaan perumahan pada dasarnya memiliki dua jenis, yaitu sebagai alat untuk memprediksi perilaku (niat untuk tinggal/pindah dari perumahan yang ada) dan sebagai kriteria untuk menilai kualitas perumahan (Weidemann dan Anderson, 1985 dalam Mohit dan Azim, 2012). Mohit dan Azim (2012) mendefinisikan kepuasan perumahan sebagai perasaan puas ketika penghuni dapat mencapai semua yang dibutuhkan dalam perumahan, dan hal ini merupakan indikator penting untuk perencana, arsitek, pengembang, dan pembuat kebijakan. Francescato et al (1979 dalam Mohit dan Azim, 2012) mendefinisikan kepuasan perumahan sebagai respon emosional seseorang terhadap hunian, perasaan positif atau negatif penghuni pada tempat tinggal mereka. Kepuasan perumahan merupakan sebuah konsep yang digunakan untuk mengevaluasi persepsi dan perasaan warga tentang rumah dan lingkungan 
mereka (Ogu, 2002 dalam Lara dan Bekker, 2012). Sumber lain mengatakan bahwa kepuasan perumahan digunakan untuk mengukur perbedaan antara lingkungan perumahan aktual dengan situasi lingkungan yang diharapkan (Galster \& Hesser, 1981 dalam Salleh, 2008).

\section{Kecenderungan Berpindah}

Keinginan untuk mendapatkan kepuasan yang lebih tinggi merupakan motif penting dalam proses pengambilan keputusan untuk berpindah (Liao, 2004). Sebagian besar pindah rumah dilakukan untuk mengurangi beberapa bentuk stres pemilik rumah ketika mereka berada pada sebuah hunian atau tempat tinggal di lingkungan yang tidak memenuhi kebutuhan dan preferensi mereka (Coulter, 2010). Pindah rumah memungkinkan keluarga dapat menyesuaikan lokasi rumahnya untuk memenuhi kebutuhan dan pereferensi yang diharapkan (Clark dan Huang 2004, dalam Coulterl, 2010). Adanya rasa kepuasan yang lebih besar dengan rumah, masyarakat, dan lingkungan perumahan telah ditemukan memiliki kontribusi untuk mengurangi kecenderungan untuk bergerak (Liao, 2004). Menggunakan indikator terpisah untuk aspek rumah dan lingkungan dari kepuasan perumahan, menemukan bahwa derajat prediksi kecenderungan mobilitas yang berhubungan dengan kepuasan lingkungan lebih tinggi daripada yang disebabkan kepuasan pada rumah (Liao, 2004).

\section{ANALISIS}

\section{Analisis Karakteristik Rumah Tangga}

Perumnas Bukit Sendangmulyo merupakan perumahan sosial yang dibangun dan ditujukan untuk masyarakat golongan menengah ke bawah. Perumnas ini dihuni oleh masyarakat dengan beraneka ragam karakteristik pekerjaan yang didominasi oleh swasta yaitu sebesar $58 \%$ dan juga PNS sebesar 20\%, sedangkan untuk sisanya yaitu $22 \%$ memiliki mata pencaharian sebagai sebagai pensiunan dan informal. Adanya berbagai jenis pekerjaan dari masyarakat tersebut memberikan pengaruh pada pendapatan rumah tangga yang diterima setiap bulannya. Rata-rata masyarakat di Perumnas Bukit Sendangmulyo memiliki pendapatan yang relatif sedang yaitu kurang dari 3 juta sebanyak (73\%). Rendahnya tingkat pendapatan rumah tangga merupakan implikasi dari rendahnya latar belakang pendidikan masyarakat dimana sebagian besar hanya berijasahkan SMA (44\%). Usia kepala rumah tangga yang memang sebagian besar masih berusia produktif yaitu berusia 41-50 tahun (40\%) dengan Jumlah anggota keluarga rata-rata adalah 4 orang (49\%) dan lama tinggal lebih dari 12 tahun (56\%).

\section{Analisis Kualitas Rumah}

Kualitas rumah di Perumnas Bukit Sendangmulyo secara umum termasuk dalam kategori cukup baik dengan nilai rata-rata 6.7 dari skala 10. Kualitas rumah pada masing-masing keluarga tentu saja sesuai kondisi keuangan masing-masing dimana sebagian besar sudah direnovasi oleh pemiliknya (73\%) bahkan dihabiskan hingga seluruh kapling. Rata-rata rumah sudah memiliki kontruksi bangunan yang baik dengan dinding terbuat dari batako dan batu bata untuk rumah yang sudah direnovasi. Sebagian besar lantai rumah juga sudah dikeramik (renovasi) sehingga nyaman bagi penghuninya. Atap rumah di Perumnas ini terdapat 2 tipe dimana yang rumah tipe RSS baik tipe 21 maupun tipe 36 menggunakan asbes dan rumah tipe 36 RS menggunakan atap dari genting. Sebagian besar rumah tangga khususnya yang berada pada rumah tipe RSS mengeluhkan penyedian rumah dari Perumnas dimana atap yang berbahan dari asbes pada siang hari dirasakan sangat panas sehingga tidak nyaman bagi penghuninya. 


\section{Analisis Kualitas Lingkungan}

Secara umum kualitas lingkungan di Perumnas Bukit Sendangmulyo sudah cukup baik karena bebas banjir, aman, tenang, prasarana yang disediakan lengkap. Pada perumnas ini sudah terdapat prasarana dasar seperti jalan, drainase, listrik, air bersih, persampahan, sanitasi, telekomunikasi. Selain itu hubungan antar tetangga sangat baik disamping juga turut membuat lingkungan perumnas menjadi lebih nyaman untuk ditinggali masyarakat. Permasalahan lingkungan yang terdapat pada perumnas ini yaitu buruknya kualitas air bersih dan pelayanan transportasi umum, sarana lingkungan yang disediakan masih kurang lengkap, dan jarak lokasi perumahan ke tempat kerja cukup jauh. Pada perumnas ini belum memiliki kelengkapan sarana pendidikan, tempat bermain, lapangan, dan juga balai pertemuan untuk beberapa RW.

\section{Analisis Kepuasan Penghuni dan Kecenderungan Berpindah}

Secara umum masyarakat di Perumnas Bukit Sendangmulyo sudah puas terhadap rumah dan lingkungan tempat tinggal mereka. Kepuasan penghuni terhadap rumah didapatkan nilai ratarata 7,2 dan kepuasan terhadap lingkungan didapatkan nilai rata-rata adalah 7,1 sehingga keduanya termasuk dalam kategori puas. Penghuni cenderung mengekspresikan kepuasan yang cukup tinggi terhadap rumah mereka karena memang sebagian besar rumah mereka sudah direnovasi sehingga cukup nyaman untuk keluarga. Masyarakat secara umum juga cenderung mengekspresikan kepuasan yang cukup tinggi pada kualitas lingkungan tempat tinggal mereka. Penghuni mengaku kondisi lingkungan mereka sudah baik karena bebas banjir, tenang, dan aman buat anak-anak mereka. Masih eratnya hubungan antar tetangga juga turut meningkatkan kepuasan mereka untuk tinggal. Selain itu adanya berbagai fasilitas seperti masjid, pasar, sekolah, dan rumah sakit yang dekat dengan rumah juga membuat mereka semakin nyaman untuk tinggal.

Masyarakat yang sudah puas dengan kondisi rumah dan lingkungan membuat niat untuk pindah dan rencana untuk pindah masyarakat Perumnas Bukit Sendangmulyo rendah dengan nilai rata-rata 3.4 dan 2.9 dari skala 10. Masyarakat lebih memilih untuk tidak berpindah karena kondisi keuangan mereka minim sehingga tidak memungkinkan untuk mampu membeli rumah baru dimana sekarang ini harganya sudah melambung tinggi dan tidak terjangkau. Dengan demikian masyarakat golongan menengah ke bawah lebih memilih bertahan dengan kondisi rumah yang seadanya dan berusaha untuk merenovasinya secara bertahap jika perekonomian rumah tangga berkembang. Hanya rumah tangga yang memiliki pendapatan tinggi saja yang memiliki niat dan rencana untuk berpindah dimana mereka rata-rata ingin pindah rumah ke lokasi yang lebih dekat dengan tempat mereka bekerja.

\section{Analisis Pengaruh Kualitas Rumah dan Lingkungan Terhadap Kepuasan Penghuni dan Kecenderungan Berpindah}

Pengembangan model dalam penelitian ini didasarkan atas kajian literatur dari berbagai sumber penelitian yang sudah dilakukan sebelumnya. Secara umum model ini terdiri atas 2 variabel independen (eksogen) dan 2 variabel dependen (endogen). Dua variabel independen tersebut adalah kualitas rumah dan kualitas lingkungan. Sedangkan variabel dependen terdiri dari kepuasan penghuni dan kecenderungan berpindah. Keempat variabel konstruk tersebut terbentuk dari 14 variabel manifes atau lebih sering disebut sebagai indikator. Model penelitian yang dibangun ini dirancang menggunakan teknik analisis yaitu analisis SEM pada program IBM SPSS Amos 21. Estimasi SEM Full Model untuk melihat kesesuaian model dan hubungan kausalitas yang dibangun dalam model terlihat seperti pada gambar berikut. 


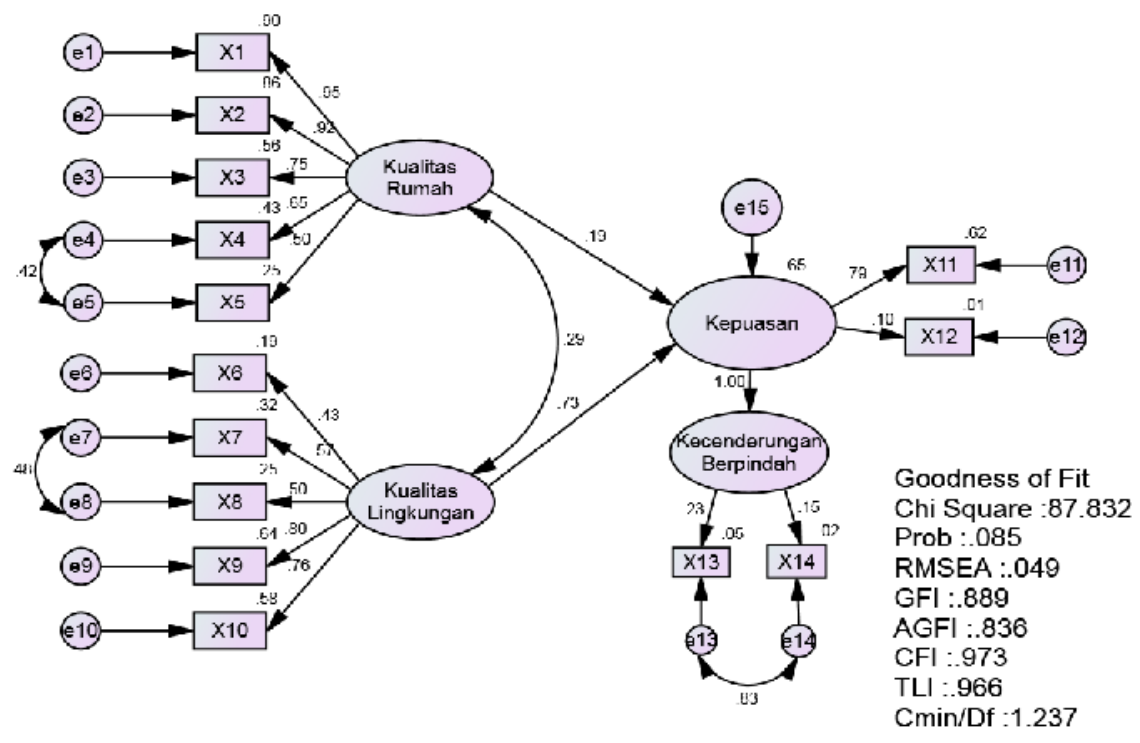

Sumber: Hasil Analisis, 2014

GAMBAR 3

ANALISIS SEM FULL MODEL

Dari gambar di atas berupa analisis konfimatori faktor yang mempengaruhi kualitas rumah dan lingkungan dihasilkan tingkat signifikansi sebesar 0,066 yang berarti lebih besar dari 0,05 sehingga secara menyeluruh model diatas fit atau dapat diterima. Dari hasil pengujian kelayakan model pada gambar diketahui bahwa konstruk eksogen pada model penelitian ini telah memenuhi kriteria uji kelayakan model yang telah ditetapkan seperti pada tabel berikut:

TABEL 2

KRITERIA UJ KELAYAKAN FULL MODEL

\begin{tabular}{|llll|}
\hline Goodness of Fit Indeks & Cut-off Value & Hasil Analisis & Evaluasi Model \\
Chi-Square & Kecil & 87.832 & Baik \\
Probability & $\geq 0.05$ & 0.085 & Baik \\
RMSEA & $\leq 0.08$ & 0.049 & Baik \\
GFI & Mendekati 1 & 0.889 & Cukup \\
AGFI & Mendekati 1 & 0.836 & Cukup \\
CFI & Mendekati 1 & 0.973 & Baik \\
TLI & Mendekati 1 & 0.966 & Baik \\
CMIN/df & $\leq 2.00$ & 1.237 & Baik \\
\hline Sumber: Hasil Analisis, 2014 & & &
\end{tabular}

Hasil analisis pengolahan data terlihat bahwa semua konstruk yang digunakan untuk membentuk sebuah model penelitian, pada proses analisis full model telah memenuhi kriteria goodness of fit yang telah ditetapkan. Uji terhadap hipotesis model menunjukkan bahwa model ini sesuai dengan data yang tersedia seperti terlihat dari tingkat signifikansi terhadap model sebesar 0,085 atau diatas 0.05. Nilai ini menunjukkan tidak adanya perbedaan antara matriks kovarian sampel dengan matriks kovarian populasi yang diestimasi, dengan demikian, konstruk-konstruk pada model penelitian dapat diterima sebagai pembentuk model yang baik. Nilai Chi Square Statistic dari analisis juga sudah kecil sehingga antara model teoritis dengan data empiris sudah memiliki kecocokan. Nilai RMSEA pada model diatas juga sudah $\leq 0,08$ sehingga model sudah memenuhi besarnya jumlah sampel. Nilai yang lain dari GFI, AGFI, TLI, 
dan CFI secara umum juga sudah mendekati 1 dengan demikian secara keseluruhan model dapat diterima. Berdasarkan analisis SEM kemudian dapat digunakan untuk melihat nilai pengaruh antar variabel seperti pada tabel berikut.

TABEL 3

KESIMPULAN HIPOTESIS PENELITIAN

\begin{tabular}{|lll|}
\hline \multicolumn{2}{|c|}{ Hipotesis } & Nilai Pengaruh \\
\hline $\mathrm{H}_{1}$ & $\begin{array}{l}\text { Kualitas rumah berpengaruh kecil terhadap kepuasan penghuni, } \\
\text { sehingga semain baik kualitas rumah maka kepuasan penghuni } \\
\text { semakin tinggi. }\end{array}$ & 0.231 \\
$\mathrm{H}_{2} \quad \begin{array}{l}\text { Kualitas lingkungan berpengaruh besar terhadap kepuasan } \\
\text { penghuni, sehingga semain baik kualitas lingkungan maka } \\
\text { kepuasan penghuni semakin tinggi. }\end{array}$ & 0.740 \\
$\mathrm{H}_{3} \quad \begin{array}{l}\text { Kepuasan penghuni berpengaruh negatif terhadap } \\
\text { kecenderungan berpindah, sehingga semakin tinggi kepuasan } \\
\text { penghuni maka kecenderungan berpindah akan semakin } \\
\text { rendah. }\end{array}$ & -0.420 \\
\hline
\end{tabular}

Sumber: Hasil Analisis, 2014

Berdasarkan tabel diatas dapat dilihat besarnya pengaruh dari kualitas rumah dan lingkungan terhadap kepuasan penghuni di Perumnas Bukit Sendangmulyo yang ditunjukkan dengan nilai estimate. Kualitas lingkungan memiliki pengaruh lebih besar dibanding kualitas rumah terhadap kepuasan penghuni ditunjukkan dengan nilai estimate 0.740 lebih besar dari 0.231 . Hipotesis 1 yaitu kualitas rumah memiliki pengaruh yang kecil terhadap kepuasan penghuni. Hal ini dapat dilihat dari lapangan bahwa sebagian besar masyarakat meskipun sudah memiliki rumah tinggal yang baik dan layak di Perumnas Bukit Sendangmulyo, mereka justru memiliki kepuasan tinggal yang rendah akibat rumah mereka yang jauh dari tempat bekerja. Selain itu sebagian rumah tangga juga mengungkapkan kepuasan yang rendah karena adanya konflik atau permasalahan antar warga di lingkungan mereka. Oleh karena itu meskipun kualitas rumah sudah baik, kepuasan penghuninya belum tentu tinggi karena faktor kepuasan rumah lebih banyak dipengaruhi oleh faktor kualitas lingkungan dibanding kualitas rumah.

Semakin baik kualitas lingkungan, maka semakin tinggi pula kepuasan tinggal penghuninya. Hipotesis kedua ini dapat diterima dan sangat signifikan karena sudah sesuai dengan berbagai teori yang sudah ada. Lingkungan telah dicatat sebagai faktor yang penting dari kepuasan bertempat tinggal seperti sekolah, klinik, toko, ruang bersama, dan lain-lain (Salleh, 2008). Penelitian yang dilakukan di Brazzil juga senada bahwa faktor utama yang berhubungan dengan kepuasaan perumahan termasuk prasarana umum seperti jalan, sistem saluran pembuangan air, dan utilitas dasar dalam kawasan perumahan (Mohit dan Azim, 2012). Kondisi ini memang sangat sesuai dengan kondisi yang ada pada Perumnas Bukit Sendangmulyo bahwa kualitas lingkungan seperti lokasi perumahan, kelengkapan prasarana, sarana, tingkat keamanan, dan hubungan bertetangga memiliki berpengaruh yang besar terhadap kepuasan penghuninya dalam bertempat tinggal. Masyarakat di Perumnas Bukit Sendangmulyo cenderung mengekspresikan kepuasan yang lebih tinggi dikarenakan lingkungan perumahan mereka yang sudah baik karena bebas banjir, terdapat infrastruktur yang lengkap, aman, tenang, dan lingkungannya aman untuk anak-anak mereka. Selain itu, meskipun sebagian masyarakat menganggap kualitas rumah mereka masih cukup buruk, mereka tetap betah tinggal di perumnas karena lingkungan perumahan yang sudah nyaman karena memiliki hubungan bertetangga yang baik dan relatif dekat dengan pasar, tempat ibadah, rumah sakit, dan juga sekolah TK dan PAUD. 
Hipotesis ketiga yaitu semakin tinggi kepuasan penghuni maka semakin rendah kecenderungan untuk berpindah memang sudah tepat sesuai dengan teori yang sudah ada. Menurut Liao (2004), adanya rasa kepuasan yang lebih besar dengan rumah, masyarakat, dan lingkungan perumahan justru memiliki kontribusi yang tinggi untuk mengurangi kecenderungan untuk bergerak. Dengan demikian semakin tinggi kepuasan penghuni, maka semakin rendah pula keinginan mereka untuk berpindah. Hal ini juga sudah sesuai dengan penelitian yang dilakukan oleh Deane (1990, dalam Liao, 2004) menggunakan indikator aspek rumah dan lingkungan dari kepuasan perumahan, ditemukan bahwa derajat prediksi kecenderungan mobilitas yang berhubungan dengan kepuasan lingkungan lebih tinggi daripada yang disebabkan kepuasan rumah. Teori tersebut sudah sesuai hasil penelitian ini bahwa kepuasan penghuni di Perumnas Bukit Sendangmulyo lebih besar dipengaruhi oleh kualitas lingkungan dibanding kualitas rumah.

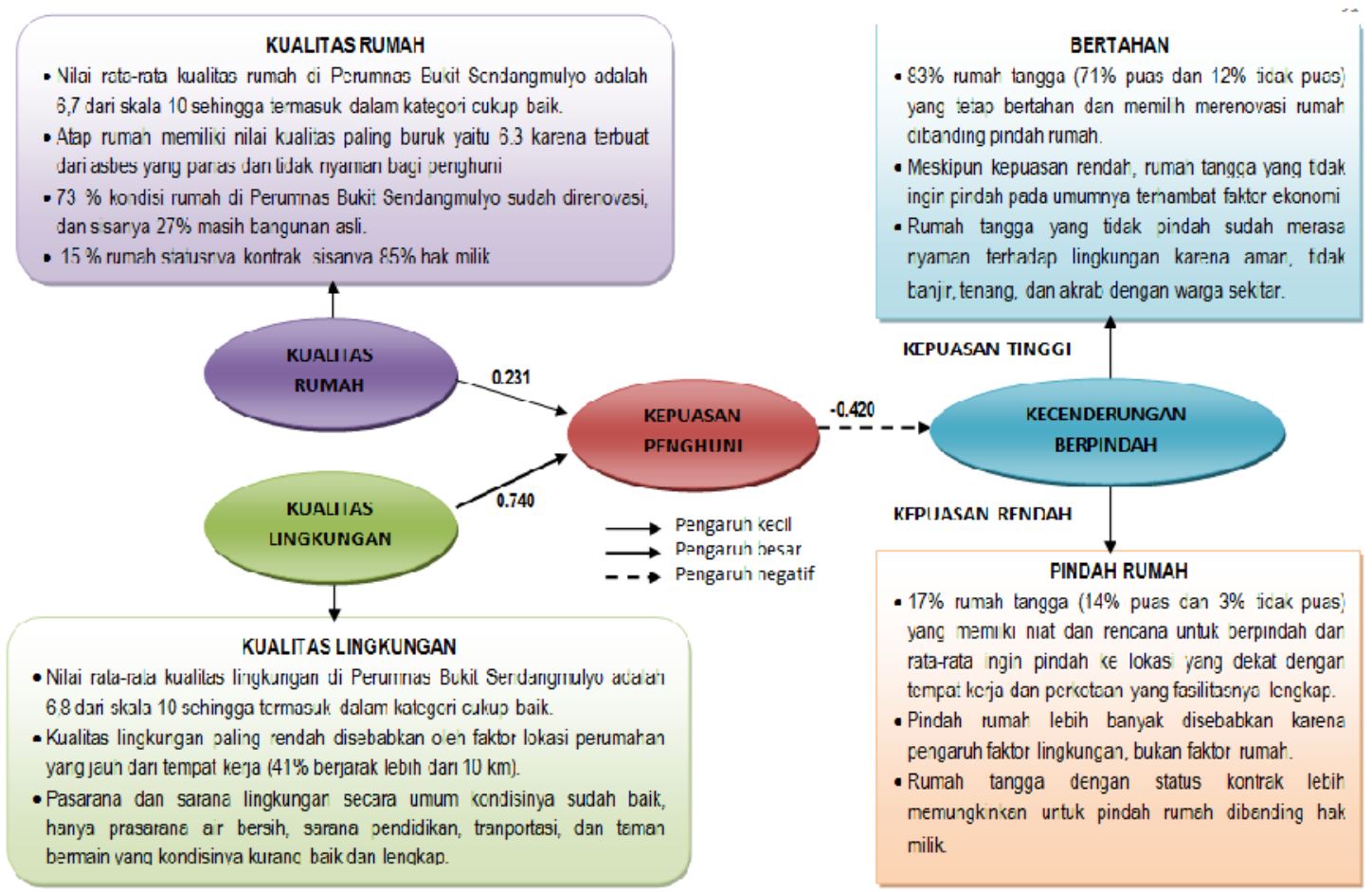

Sumber: Hasil Analisis, 2014

\section{GAMBAR 4 \\ DIAGRAM TEMUAN STUDI PENGARUH KUALITAS RUMAH DAN LINGKUNGAN PADA KEPUASAN PENGHUNI DAN KECENDERUNGAN BERPINDAH}

Pindah rumah memungkinkan keluarga dapat menyesuaikan lokasi rumahnya untuk memenuhi kebutuhan dan pereferensi yang diharapkan (Clark dan Huang 2004, dalam Coulter, 2010). Hal ini juga sesuai dengan kondisi di Perumnas Bukit Sendangmulyo bahwa sebagian besar rumah tangga yang ingin berpindah rumah disebabkan karena faktor lokasi yaitu rumah mereka jauh dengan tempat kerja. Bagi masyarakat yang memiliki pendapatan tinggi pindah rumah tidak menjadi persoalan karena mereka dapat menjual rumahnya dan mampu untuk membeli atau membangun rumah ditempat lain sesuai keinginan. Kondisi tersebut sangat berbeda bagi masyarakat menengah ke bawah, walaupun memiliki kepuasan bertempat tinggal yang rendah dan keinginan untuk berpindah tinggi, mereka tidak dapat pindah karena terhambat oleh faktor ekonomi. Rumah tangga dengan pendapatan yang minim lebih memilih untuk tetap bertahan meskipun kondisi rumah dan lingkungan belum sesuai dengan yang diharapkan. 
Mereka lebih memilih merenovasi rumahnya secara bertahap sesuai dengan meningkatnya perekonomian karena jika pindah tempat lain pun harga rumah sudah tinggi dan tidak mungkin dapat terjangkau bagi mereka.

\section{KESIMPULAN}

Kualitas lingkungan secara signifikan memiliki pengaruh besar terhadap kepuasan penghuni di Perumnas Bukit Sendangmulyo dengan nilai estimate sebesar 0.740 , sedangkan untuk kualitas rumah memiliki pengaruh yang kecil terhadap kepuasan penghuni dengan nilai estimate sebesar 0.231. Oleh karena itu semakin baik kualitas rumah dan lingkungan maka tingkat kepuasan penghuninya juga semakin tinggi. Kepuasan penghuni berpengaruh negatif terhadap kecenderungan berpindah dengan nilai estimate sebesar -0.420 , sehingga semakin tinggi kepuasan penghuni maka kecenderungan berpindah akan semakin rendah. Hal ini sesuai dengan teori yang di ungkapkan oleh Liao (2004), adanya rasa kepuasan yang lebih besar dengan rumah, masyarakat, dan lingkungan perumahan justru memiliki kontribusi yang tinggi untuk mengurangi kecenderungan untuk bergerak. Sebagian masyarakat meskipun menganggap kualitas rumah mereka masih cukup buruk, masyarakat tetap betah tinggal di perumnas dan cenderung mengekspresikan kepuasan tinggi dikarenakan faktor lingkungan mereka yang sudah baik seperti bebas banjir, terdapat infrastruktur yang lengkap, aman, tenang, hubungan antar tetangga baik, dan relatif dekat dengan pasar, tempat ibadah, rumah sakit, dan juga sekolah TK dan PAUD. Kondisi ini sesuai dengan penelitian yang dilakukan oleh Salleh (2008) bahwa lingkungan telah dicatat sebagai faktor yang penting dari kepuasan bertempat tinggal seperti sekolah, klinik, toko, ruang bersama, dan lain-lain. Pindah rumah memang memungkinkan keluarga dapat menyesuaikan lokasi rumahnya untuk memenuhi kebutuhan dan pereferensi yang diharapkan (Clark dan Huang 2004, dalam Coulter, 2010). Hal ini juga sesuai dengan kondisi di Perumnas Bukit Sendangmulyo bahwa sebagian besar rumah tangga yang ingin berpindah rumah, hampir keseluruhan disebabkan karena faktor lokasi yaitu rumah mereka jauh dengan tempat kerja. Rumah tangga yang tetap bertahan dan lebih memilih merenovasi rumah pada umumnya terhambat faktor ekonomi.

\section{DAFTAR PUSTAKA}

Coulter, Rory et al. 2010. "A Longitudinal Analysis of Moving Desires, Expectations and Actual Moving Behaviour.” Discussion Paper Series. No. 5277.

Lara, T. and M.C. Bekker. 2012. "Resident Satisfaction as a Project Wuality Measure: The Case of Nova Vida Housing Project, Angola.” Jurnal of Contemporary management. Vol. 9, pp. 364-381.

Liao, Pei-Shan. 2004. "Emotional Attachment, Residential Satisfaction, and Mobility Propensity." Center for Survey Research TYRC, Academia Sinica. Vol. 28, pp. 49-79.

Mohit, Mohammad Abdul and Mohamed Azim. 2012. "Assesment of Residential Satisfaction with public Housing in Hulhumale, Maldives." Procedia-Social and Behavioral Sciences. Vol. 50, pp. 756-770.

Mustafa, Zainal dan Tony Wijaya. 2012. Panduan Teknik Statistik SEM \& PLS dengan SPSS AMOS. Yogyakarta: Cahaya Atma Pustaka.

Salleh, Abdul Ghani. 2008. "Neighborhood Factor in Private Low-cost Housing in Malaysia." Habitat International. Vol. 32, pp. 485-493.

Santoso, Jo dkk. 2002. Sistem Perumahan Sosial di Indonesia. Pusat Studi Perkotaan: Universitas Indonusa. 
Sugiyono. 2012. Metode Penelitian Kuantitatif Kualitatif dan R\&D. Bandung: Alfabeta.

Widiastomo, Yudhi. 2013. "Kepuasan penghuni berdasarkan kualitas lingkungan di Perumnas Bukit Sendangmulyo." Tugas Akhir tidak diterbitkan, Jurusan Perencanaan Wilayah dan Kota, Fakultas Teknik, Universitas Diponegoro, Semarang. 